\title{
Peritoneal Shunt Catheter Migration into the Stomach: Case Report and Review of Literature
}

\author{
Yala Kirthi Reddy ${ }^{1}$, Shilpa Lingala ${ }^{1}$ and Nazneen Ahmed ${ }^{1,3}$ \\ ${ }^{1}$ Department of Internal Medicine, University of Tennessee Health Science Center, USA \\ ${ }^{2}$ Veterans Affairs Medical Center, USA
}

Submission: February 01, 2019; Published: March 11, 2019

"Corresponding author: Yala Kirthi Reddy, Department of Internal Medicine, University of Tennessee Health Science Center, 142 harbor creek drive, Memphis, TN 38103, Memphis, Tennessee, USA

Keywords: Ventriculoperitonea; Hydrocephalus; Peritoneal pseudocyst; Peritonitis; Intra-abdominal; Gastrointestinal tract; Intra-abdominal; CSF infection; Stomach; Iron deficiency; Anemia; Bowel perforation; Shunt catheter; Peptic ulcer

\section{Introduction}

Ventriculoperitoneal (VP) shunting is commonly performed for the treatment of hydrocephalus. Various complications have been reported in the neurosurgery literature post VP shunt placement including shunt migration, infection into the CSF, peritonitis and peritoneal pseudocyst. Bowel perforation secondary to migration of a VP shunt can occur anywhere in the gastrointestinal tract. The overall frequency of bowel perforation is about 0.01 to $0.03 \%$ and the colon is the most common site $[1,2]$. Patients with bowel perforations do not always present with typical symptoms. 19 of the 45 cases of bowel perforation were identified and managed at an asymptomatic stage [3]. However, morbidity and mortality increase if a patent presents with sepsis secondary to serious intra-abdominal or CSF infection. Therefore, early diagnosis is critical. Migration into the stomach is quite unusual, with only 11 cases reported [4]. We report a case of migration of a VP shunt catheter into the stomach, in a patient who presented with iron deficiency anemia.

\section{Case Report}

A 65-year-old African American woman was referred because of iron deficiency anemia. She had no gastrointestinal symptoms and fecal immunochemical test was negative 3 months ago. Colonoscopy was unremarkable. EGD showed no evidence of peptic ulcer disease or any arteriovenous malformation up until the 4 th part of duodenum. Incidentally, it was noted that she had a foreign body protruding into the gastric fundus (Figure 1). On review of her past medical history, she had a VP shunt procedure in 1995 after clipping of an intracranial aneurysm. She also had a shunt revision in 2015. CT of abdomen confirmed the present of the VP shunt in the stomach (Figure 2). The tip of the tube appeared to be buried within the greater curvature of the stomach.

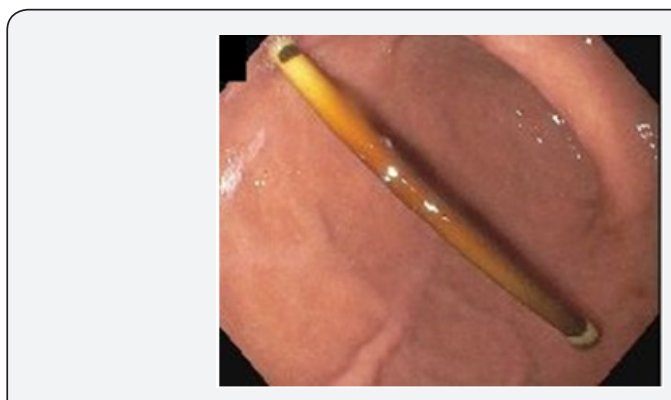

Figure 1:Foreign body protruding into the gastric fundus.

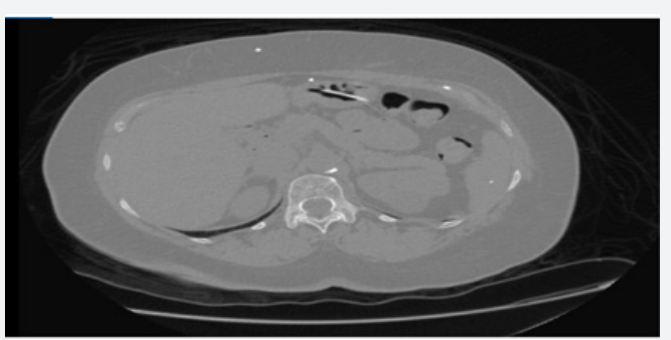

Figure 2:CT of abdomen confirmed the present of the VP shunt in the stomach.

After discussion with Neurosurgery, the patient was referred to Surgery for laparoscopic revision of the VP shunt and repair of the gastrotomy. During surgery, approximately 5-6 cm of the dis- 
tal tip of the VP shunt was intragastric and had formed a fistula between the stomach and the abdominal wall; dense intra-abdominal adhesions were noted. The fistula tract was sealed and the shunt was repositioned intraperitoneally. The patient was stable after the surgery and was discharged home after 3 days.

\section{Discussion}

From a review of the literature, our patient's presentation with anemia and no abdominal pain was unusual. Only 11 cases of intragastric migration of a peritoneal catheter have been described [4]. Only one case was secondary to surgical error. Most patients complained of abdominal discomfort prior to the intragastric perforation. This complication predominantly affects children. The plausible explanation for this is weak bowel musculature and vigorous peristaltic activity. The most common symptom of bowel perforation is protrusion of distal shunt catheter through the anus $[1,5]$. This accounts for 27 of the total 50 cases reported so far. Oral protrusion of the catheter was reported in 3 cases [1]. Cheng et al. [6] from Taiwan described an 87-year-old man, who presented with coffee ground emesis; upper endoscopy showed the shunt in the anterior wall of the greater curvature of the stomach with ulceration and active bleeding. Our patient could also have had chronic gastric bleeding which may have contributed to her iron deficiency anemia.

The mean interval between the last shunt procedure and perforation was approximately 18.7 months ranging from 1 day to 12 yrs [1] and is unpredictable. Two possible mechanism of bowel perforation have been postulated [5]. First, the catheter may adhere to the serosal surface of the stomach causing a foreign body reaction and resulting fibrosis. The continuous pressure from the catheter tip eventually leads to perforation. However, free perforation into the peritoneum is prevented because of the surrounding fibrosis. Alternatively, an allergic / immunogenic reaction to silicone or latex has also been implicated as a possible mechanism.

Treatment approaches include injection of fibrin glue along the catheter tract to close the perforated stomach wall, and direct suture of the stomach wall by laparotomy. In our patient, the latter approach was taken. Intragastric perforation is a very rare complication of VP shunting, but the clinical features are important to recognize. As far as we are aware, this is the only reported case of a patient with intragastric migration of a VP shunt presenting with iron deficiency anemia.

\section{Conclusion}

Migration of VP shunt is a rare condition and most commonly seen in children. Migration of VP shunt presenting as iron deficiency anemia has not been reported earlier. Management generally includes surgical correction of the perforation.

\section{References}

1. Park CK, Wang KC, Seo JK, Cho BK (2000) Transoral protrusion of a peritoneal catheter: a case report and literature review. Childs Nerv Syst 16(3): 184-189.

2. Janjua KJ, Ashraf AN, Sendi A (1995) Colonic perforation: rare complication of CSF shunt. Br J Clin Pract 49(1): 44-45.

3. Sathyanarayana S, Wylen EL, Baskaya MK, Nanda A (2000) Spontaneous bowel perforation after ventriculoperitoneal shunt surgery: case report and a review of 45 cases. Surg Neurol 54(5): 388-396.

4. Masuoka J, Mineta T, Kohata T, Tabuchi K (2005) Peritoneal shunt tube migration into the stomach--case report. Neurol Med Chir (Tokyo) 45(10): 543-546.

5. Abu-Dalu K, Pode D, Hadani M, Sahar A (1983) Colonic complications of ventriculoperitoneal shunts. Neurosurgery 13(2): 167-169.

6. Cheng JY, Lo WC, Liang HH, Kun IH (2007) Migration of ventriculoperitoneal shunt into the stomach, presenting with gastric bleeding. Acta Neurochir (Wien) 149(12): 1269-1270.
Your next submission with JuniperPublishers will reach you the below assets

- Quality Editorial service

- Swift Peer Review

- Reprints availability

- E-prints Service

- Manuscript Podcast for convenient understanding

- Global attainment for your research

- Manuscript accessibility in different formats ( Pdf, E-pub, Full Text, audio)

- Unceasing customer service

Track the below URL for one-step submission https://juniperpublishers.com/online-submission.php 